\title{
12. ABUNDANCES OF RARE EARTHS AND OTHER TRACE ELEMENTS LEG 46 BASALTS (DSDP)
}

\author{
R. Emmermann and H. Puchelt, Institut für Petrographie und Geochemie der Universität (T.H.) Karlsruhe, Germany
}

\begin{abstract}
On a total of 25 basalt samples drilled in Hole 396B (Leg 46) the rare earth elements $\mathrm{La}, \mathrm{Ce}, \mathrm{Sm}, \mathrm{Nd}, \mathrm{Eu}, \mathrm{Tb}, \mathrm{Dy}, \mathrm{Yb}$, and $\mathrm{Lu}$ and the trace elements $\mathrm{Li}, \mathrm{F}, \mathrm{Sc}, \mathrm{V}, \mathrm{Cr}, \mathrm{Ni}, \mathrm{Zn}, \mathrm{Sr}$, and $\mathrm{Hf}$ have been determined by INAA and AAS. The data obtained indicate that there are no large-scale differences between basalts from different lithologic units met in this hole. However, minor differences do exist, which are especially pronounced in case of the REE.

All basalts analyzed are LREE depleted and exhibit smooth distribution patterns. Basalts from Lithologic Unit 4 differ from those of the other units by a very low overall enrichment of the REE compared to chondrite. The average concentrations of $\mathrm{Sc}, \mathrm{V}, \mathrm{Zn}$, and $\mathrm{Hf}$ are also lowest in this unit, whereas $\mathrm{Cr}$ and $\mathrm{Ni}$ are highest. The differences are in keeping with petrographic features and can be explained by the special mineralogical composition of these basalts. According to the RE abundances and the concentrations of the other trace elements all rocks investigated can be classified as "typical" mid-ocean ridge basalts. The basaltic magmas are derived from a LREE depleted mantle source; it is assumed, that these magmas have not undergone any large-scale differentiation after their formation.
\end{abstract}

\section{INTRODUCTION}

A 255-meter-thick section of basalt, basaltic breccia, gravel, and sand was drilled in Hole 396B during Leg 46. The hole is located about $160 \mathrm{~km}$ east of the Mid-Atlantic Ridge (at $22^{\circ} 59.1^{\prime} \mathrm{N}$ and $43^{\circ} 30.9^{\prime} \mathrm{W}$ ) on magnetic anomaly $5 \mathrm{~A}$ (13 m.y.). The basement rocks, overlain by 150 meters of sediments, were subdivided into eight lithologic units by the shipboard scientific staff (Dmitriev, Heirtzler et al., 1976).

Units 1 and 2 (150.5-235.5 m) consist of sparsely phyric pillow basalts with less than 1 per cent phenocrysts of olivine and plagioclase in equal amounts. Unit 3 is a sparsely phyric basalt flow (less than $1 \%$ olivine and plagioclase phenocrysts) with a thickness of 8.5 meters. Unit 4 $(243.0-315.0 \mathrm{~m})$ represents a highly phyric pillow basalt sequence with phenocrysts of plagioclase (10.4 to $20.4 \%$ ) and olivine ( 1.3 to $6.0 \%$ ). Units 5 through 8 (Cores 23 to 33 ) comprise a sequence of pillow basalt, sand, and gravel.

Forty-one samples of the basalts were analyzed on shipboard by XRF for all major oxides except $\mathrm{Na}_{2} \mathrm{O}$ and the trace elements $\mathrm{Zr}, \mathrm{Sr}, \mathrm{Ni}$, and $\mathrm{Cr}$; additionally, $\mathrm{H}_{2} \mathrm{O}$ and $\mathrm{CO}_{2}$ were determined using a $\mathrm{CHN}$-analyzer. On the basis of these analyses, all rocks can be classified as typical oceanic tholeiites, with only limited chemical variation. The ranges of variation for the major oxides (given on a dry weight basis) are: $\mathrm{SiO}_{2}=49-51 \% ; \mathrm{TiO}_{2}=0.9-1.7 \% ; \mathrm{Al}_{2} \mathrm{O}_{3}=15-18 \%$; $\mathrm{FeO}($ total $\mathrm{Fe})=7.4-10.4 \% ; \mathrm{MgO}=7-9 \% ; \mathrm{CaO}=$ $10.8-12.8 \% ; \mathrm{K}_{2} \mathrm{O}=0.1-0.35 \%$. For the trace elements the following limits were found: $\mathrm{Zr}=60-130 \mathrm{ppm} ; \mathrm{Sr}=$ $110-170 \mathrm{ppm} ; \mathrm{Ni}=110-160 \mathrm{ppm}$; and $\mathrm{Cr}=250-370 \mathrm{ppm}$.

Despite this small variability, four major chemical units could be established using $\mathrm{TiO}_{2}$ as the most effective single discriminant. Unit A (Cores 4 to 15) corresponds to lithologic
Units 1, 2, and 3; and Unit B (Cores 16 to 22) to lithologic Unit 4. Unit C (Cores 23 to 32 ) represents the basaltic breccia, sand, and gravel sequence, and Unit D (Core 32, Section 1, $60 \mathrm{~cm}$ through Core 33) consists of pillow basalts. From step-like chemical changes between the units and a relative homogeneity within each unit, it was concluded that these chemically defined units represent discrete magma batches (Dmitriev, Heirtzler, et al., 1976).

On the basis of the shipboard results, 25 basalt samples, representative of the entire compositional spectrum, were selected by us for the determination of further trace elements. We were chiefly concerned with analysis of the rare earths (REE) $\mathrm{La}, \mathrm{Ce}, \mathrm{Nd}, \mathrm{Sm}, \mathrm{Eu}, \mathrm{Tb}, \mathrm{Dy}, \mathrm{Yb}$, and $\mathrm{Lu}$, because abundances of these elements (a) provide a rather specific mean for characterizing basalts and in discriminating between the various types, and (b) may also yield some information on the processes involved in generation of basaltic magma. In addition to rare earths, the concentrations of $\mathrm{Li}, \mathrm{F}, \mathrm{Sc}, \mathrm{V}, \mathrm{Cr}, \mathrm{Ni}, \mathrm{Zn}, \mathrm{Sr}$, and $\mathrm{Hf}$ were determined.

The purpose of this paper is to provide additional data for the chemical characterization of the basalts, to investigate downhole variation of the basaltic profile, and to evaluate, if possible, the petrogenetic processes responsible for generation of the basalt types sampled.

\section{ANALYTICAL METHODS, PRECISION AND ACCURACY}

The rare earths $\mathrm{La}, \mathrm{Ce}, \mathrm{Nd}, \mathrm{Sm}, \mathrm{Eu}, \mathrm{Tb}, \mathrm{Dy}, \mathrm{Yb}$, and $\mathrm{Lu}$, and the elements $\mathrm{Sc}, \mathrm{Cr}$, and $\mathrm{Hf}$ were determined by instrumental neutron activation analysis (INAA). The analytical procedure is shown in a flow diagram in Figure 1. Before analysis, the material was ground in an agate mortar 


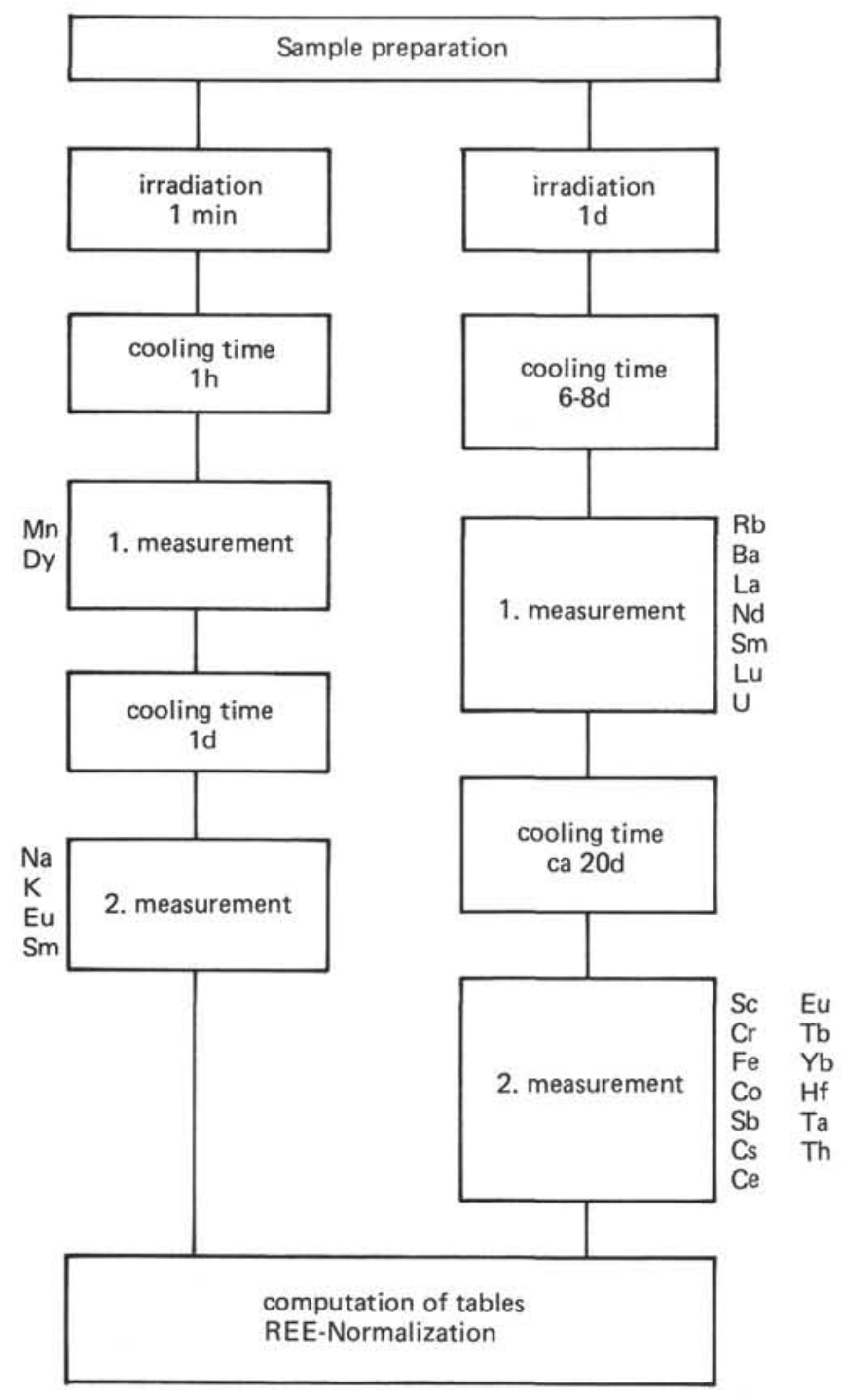

Figure 1. Flow diagram of INAA determinations.

to a grain size of less than $100 \mu \mathrm{m}$ and dried at $105^{\circ} \mathrm{C}$ for five hours. Two reactor irradiations were carried out with each of the investigated samples. An irradiation of one day enables determination of all elements with half-lives of more than one and one-half days. For this purpose, about $100 \mathrm{mg}$ of sample material is packed into Al-capsules and irradiated together with single element standards (Puchelt, et al., 1976) in modified Harwell cans at a thermal neutron flux of $8 \times 10^{13}$ $\mathrm{n} / \mathrm{cm}^{2} \mathrm{~s}$ in the research reactor FR-2 in Karlsruhe. After a cooling time of six to eight days, the sample material is unpacked and weighed into special sample holders. The first measurement allows all elements with half-lives up to 18 days to be determined with good precision. A further cooling time of three weeks improves the detection limit of elements with a decay time longer than 18 days.

The short-lived isotopes of $\mathrm{Sm}, \mathrm{Eu}$, and Dy are determined by a one-minute irradiation in the pneumatic tube. Samples of 50 to $80 \mathrm{mg}$ are weighed for this purpose in capsules of polyethylene of the highest purity. In this case also irradiation is performed simultaneously with the respective single element standards. The best results for these elements are obtained after a cooling time of one hour (Dy) or one day (Sm, Eu).

For measurement of the $\delta$ spectra, a coaxial $\mathrm{Ge}(\mathrm{Li})$ detector with a resolution of $2.3 \mathrm{keV}$ at $1.33 \mathrm{MeV}$ and an effeciency 10 per cent, and a high purity planar Ge-detector with an effective area of $200 \mathrm{~mm}^{2}, 7 \mathrm{~mm}$ thickness, and a resolution of $540 \mathrm{eV}$ at $122 \mathrm{KeV}$ is available. Both detectors are connected to multichannel analyzers (Nuclear Data 2200 and Canberra 8100), which are equipped with 4096 channels and $100-\mathrm{MHz}$ ADC's, and are coupled to a HP 2100 computer. Evaluation of the spectra and computation of element concentrations are performed by our computer program GAMMA (Puchelt, et al., 1976). The elements Li, V, Cr, $\mathrm{Ni}, \mathrm{Zn}$, and $\mathrm{Sr}$ were determined in highly concentrated solutions ( 10 grams of sample per liter) by atomic absorption spectrometry (Varian VAAG and Perkin-Elmer 303). For the determination of fluoride, a fluoride-specific ion electrode (Orion 94-09) was used. The analyses were performed without separation of aluminum following the procedure described by Ingram (1970).

The precision of the methods used was tested by replicate measurements of selected samples; the accuracy was always checked by carrying samples of the international reference rocks BCR-1, AGV-1, GSP-1, BR, and BM through the whole procedure along with each series of Leg 46 samples. The values obtained by us for BCR-1 are given in Table 1 in comparison to the recommended values (Flanagan, 1973). This table also includes our data for the interlaboratory "standards"' 1, 2, and 3 (Leg 46 basalts), which were distributed among the laboratories involved in the analyses of Leg 46 samples (see Kirkpatrick, this volume). The precision ( $2 \sigma$ in relative percent) for the elements analyzed within the concentration range of these "standards" is given in the last colume of Table 1; it varies between 5 per cent for $\mathrm{Sc}$ and $\mathrm{Tb}$ and 20 per cent for $\mathrm{Ce}, \mathrm{Nd}$, and $\mathrm{Hf}$.

\section{RESULTS}

The abundances of the 18 trace elements determined in the basalts from Hole $396 \mathrm{~B}$ are summarized in Table 2 . The

TABLE 1

Analytical Results (in ppm) for BCR-1 and the Three Leg 46 Interlaboratory "Standards"

\begin{tabular}{|c|c|c|c|c|c|c|}
\hline \multirow[b]{2}{*}{ Element } & \multicolumn{2}{|c|}{ BCR-1 } & \multicolumn{3}{|c|}{ Leg 46 "Standards" } & \multirow{2}{*}{$\begin{array}{c}\text { Precision } \\
2 \sigma \text { (relative } \%)\end{array}$} \\
\hline & This Work & (1973) & No. 1 & No. 2 & No. 3 & \\
\hline $\mathrm{Li}$ & 12 & 12.8 & 11 & 7 & 13 & 10 \\
\hline $\mathrm{F}$ & 453 & 470 & 181 & 164 & 150 & 10 \\
\hline $\mathrm{Sc}$ & 32 & 33 & 38.5 & 39.7 & 31.8 & 5 \\
\hline V & 400 & 399 & 244 & 193 & 156 & 15 \\
\hline $\mathrm{Cr}_{\mathrm{r}}$ & 18 & 17.6 & 343 & 301 & 369 & 10 \\
\hline $\mathrm{Ni}$ & 15 & 15.8 & 158 & 133 & 120 & 10 \\
\hline $\mathrm{Zn}$ & 114 & 120 & 56 & 66 & 50 & 10 \\
\hline $\mathrm{Sr}$ & 335 & 330 & 125 & 143 & 110 & 10 \\
\hline $\mathrm{La}$ & 27 & 26 & 2.6 & 4.0 & 2.4 & 10 \\
\hline $\mathrm{Ce}$ & 50 & 53.9 & 9.5 & 11.6 & 6.7 & 10 \\
\hline $\mathrm{Nd}$ & 31 & 29.0 & 7.8 & 11.9 & 7.4 & 10 \\
\hline $\mathrm{Sm}$ & 6.5 & 6.6 & 3.4 & 4.1 & 2.4 & 15 \\
\hline $\mathrm{Eu}$ & 1.90 & 1.94 & 1.15 & 1.39 & 0.83 & 10 \\
\hline $\mathrm{Tb}$ & 1.4 & 1.0 & 0.87 & 0.96 & 0.60 & 5 \\
\hline Dy & 5.6 & 6.3 & 5.5 & 6.7 & 3.5 & 15 \\
\hline $\mathrm{Yb}$ & 3.6 & 3.4 & 2.8 & 3.2 & 2.2 & 10 \\
\hline $\mathrm{Lu}$ & 0.52 & 0.55 & 0.50 & 0.57 & 0.38 & 10 \\
\hline $\mathrm{Hf}$ & 5.1 & 4.7 & 2.5 & 2.9 & 1.5 & 20 \\
\hline
\end{tabular}


TABLE 2

Concentrations (in ppm) of 18 Trace Elements in Leg 46 Basalts

\begin{tabular}{|c|c|c|c|c|c|c|c|c|c|c|c|c|c|c|c|c|c|c|c|c|}
\hline $\begin{array}{c}\text { Sample } \\
\text { (Interval in cm) }\end{array}$ & $\begin{array}{l}\text { Sub-basement } \\
\text { Depth }(\mathrm{m})\end{array}$ & $\begin{array}{l}\text { Lithologic } \\
\text { Unit }\end{array}$ & Li & $\mathrm{F}$ & Sc & V & $\mathrm{Cr}$ & $\mathrm{Ni}$ & $\mathrm{Zn}$ & $\mathrm{Sr}$ & La & $\mathrm{Ce}$ & $\mathrm{Nd}$ & $\mathrm{Sm}$ & $\mathrm{Eu}$ & $\mathrm{Tb}$ & Dy & $\mathrm{Yb}$ & Lu & $\mathrm{Ht}$ \\
\hline $4-1,80-87$ & 2.20 & 1 & 10 & 140 & 37 & 220 & 327 & 142 & 68 & 132 & 3.4 & 9.5 & 9.9 & 3.3 & 1.22 & 0.87 & 6.3 & 3.6 & 0.65 & 2.0 \\
\hline $5-2,87-93$ & 10.99 & 1 & 7 & 140 & 37 & 260 & 312 & 142 & 59 & 124 & 3.8 & 9.9 & 9.4 & 3.9 & 1.19 & 0.94 & 5.1 & 3.4 & 0.54 & 1.8 \\
\hline $7-1,25-30$ & 24.28 & 1 & 11 & 200 & 38 & 260 & 330 & 149 & 72 & 134 & 4.9 & 11.4 & 9.3 & 3.5 & 1.20 & 0.89 & 5.9 & 3.7 & 0.64 & 1.9 \\
\hline $7-1,60-62$ & 25.26 & 1 & 25 & 290 & 36 & 170 & 315 & 151 & 76 & 118 & 2.7 & 9.5 & 9.8 & 3.6 & 1.21 & 0.92 & 5.7 & 3.6 & 0.55 & 2.4 \\
\hline $7-2,107-113$ & 30.99 & 1 & 13 & 170 & 38 & 295 & 335 & 147 & 62 & 132 & 3.1 & 9.4 & 10.0 & 3.7 & 1.15 & 0.84 & 5.7 & 3.4 & 0.63 & 2.0 \\
\hline $8-1,128-135$ & 38.29 & 1 & 14 & 160 & 39 & 385 & 301 & 139 & 75 & 142 & 4.1 & 11.5 & 10.1 & 3.9 & 1.28 & 0.99 & 5.9 & 3.9 & 0.57 & 2.3 \\
\hline $9-1,75-80$ & 44.62 & 1 & 14 & 150 & 40 & 375 & 299 & 136 & 68 & 143 & 3.3 & 11.3 & 10.0 & 4.2 & 1.23 & 1.14 & 6.4 & 4.0 & 0.75 & 2.7 \\
\hline $11-1,104-108$ & 62.78 & 1 & 13 & 200 & 38 & 360 & 298 & 149 & 70 & 137 & 4.1 & 10.4 & 9.4 & 3.7 & 1.16 & 0.87 & 6.5 & 3.6 & 0.65 & 2.0 \\
\hline $11-2,27-33$ & 63.68 & 1 & 29 & 230 & 38 & 305 & 294 & 126 & 80 & 140 & 3.2 & 9.6 & 8.7 & 3.6 & 1.18 & 0.82 & 6.3 & 3.6 & 0.53 & 2.1 \\
\hline $14-1,121-127$ & 77.91 & 2 & 27 & 300 & 38 & 305 & 279 & 153 & 61 & 154 & 4.7 & 12.8 & 10.8 & $4.2^{\circ}$ & 1.39 & 1.00 & 6.9 & 4.1 & 0.65 & 2.4 \\
\hline $15-1,116-120$ & 87.07 & 3 & 31 & 210 & 38 & 260 & 290 & 151 & 68 & 157 & 4.9 & 13.0 & 11.2 & 4.2 & 1.32 & 0.90 & 6.6 & 3.7 & 0.62 & 2.5 \\
\hline $15-2,111-115$ & 87.89 & 3 & 7 & 160 & 38 & 320 & 289 & 142 & 73 & 148 & 4.4 & 13.1 & 11.8 & 4.1 & 1.30 & 1.01 & 6.7 & 3.8 & 0.66 & 2.5 \\
\hline $15-4,13-20$ & 90.69 & 3 & 7 & 160 & 38 & 320 & 282 & 149 & 66 & 148 & 3.9 & 10.6 & 9.7 & 3.9 & 1.30 & 1.02 & 6.2 & 3.9 & 0.62 & 2.4 \\
\hline $15-4,132-141$ & 92.29 & 3 & 8 & 180 & 37 & 305 & 282 & 145 & 76 & 152 & 4.1 & 10.3 & 9.6 & 3.9 & 1.34 & 0.92 & 6.3 & 3.8 & 0.67 & 2.5 \\
\hline $16-1,97-102$ & 97.08 & 4 & 13 & 200 & 31 & 260 & 315 & 145 & 58 & 135 & 2.4 & 7.4 & 7.2 & 2.6 & 0.98 & 0.76 & 4.9 & 2.8 & 0.44 & 2.0 \\
\hline $16-4,63-68$ & 110.02 & 4 & 15 & 130 & 34 & 250 & 309 & 136 & 73 & 134 & 3.1 & 8.9 & 7.8 & 3.0 & 1.04 & 0.75 & 4.2 & 2.9 & 0.52 & 1.9 \\
\hline $16-5,34-36$ & 113.75 & 4 & 26 & 240 & 32 & 220 & 310 & 139 & 25 & 138 & 2.9 & 8.8 & 7.4 & 2.7 & 0.99 & 0.66 & 4.9 & 2.9 & 0.49 & 1.6 \\
\hline $20-1,35-42$ & 136.45 & 4 & 13 & 180 & 32 & 295 & 308 & 134 & 61 & 144 & 2.4 & 6.5 & 8.5 & 3.1 & 1.00 & 0.67 & 4.5 & 2.5 & 0.48 & 1.6 \\
\hline $20-3,21-27$ & 139.82 & 4 & 25 & 200 & 28 & 277 & 312 & 153 & 48 & 137 & 2.4 & 6.7 & 7,3 & 2.2 & 0.88 & 0.66 & 4.0 & 2.3 & 0.37 & 2.0 \\
\hline $21-1,3-10$ & 145.78 & 4 & 11 & 170 & 32 & 220 & 356 & 151 & 50 & 133 & 2.8 & 7.2 & 8.3 & 2.4 & 0.98 & 0.70 & 4.5 & 2.5 & 0.49 & 2.1 \\
\hline $21-1,102-110$ & 150.53 & 4 & 13 & 120 & 31 & 250 & 343 & 155 & 47 & 129 & 2.6 & 6.4 & 7.2 & 2.2 & 0.86 & 0.67 & 4.6 & 2.5 & 0.46 & 1.4 \\
\hline $22-2,8-12$ & 157.88 & 4 & 13 & 160 & 29 & 185 & 345 & 183 & 54 & 121 & 1.8 & 6.2 & 6.9 & 1.9 & 0.82 & 0.60 & 5.0 & 2.4 & 0.35 & 1.3 \\
\hline $22-4,4-9$ & 163.21 & 4 & 6 & 120 & 30 & 220 & 357 & 168 & 46 & 128 & 2.2 & 6.6 & 6.8 & 2.0 & 0.81 & 0.55 & 4.7 & 2.2 & 0.43 & 1.1 \\
\hline $32-1,11-13$ & 237.09 & 7 & 13 & 280 & 33 & 260 & 329 & 139 & 61 & 161 & 4.0 & 10.0 & 9.0 & 2.7 & 1.10 & 0.76 & 5.6 & 3.1 & 0.62 & 2.0 \\
\hline $32-1,59-62$ & 241.43 & 7 & 20 & 270 & 36 & 340 & 276 & 143 & 72 & 142 & 5.0 & 12.5 & 11.6 & 3.7 & 1.33 & 0.99 & 7.0 & 3.9 & 0.61 & 2.6 \\
\hline
\end{tabular}

numbering of the samples is according to standard DSDP procedure (i.e., Core No., Section No., interval in $\mathrm{cm}$ ). For each sample sub-bottom depth is also given along with its stratigraphic position.

In addition to presentation of the REE data in tabular form, the chondrite-normalized REE abundances are shown graphically (Figures 2-5). For the normalization procedure the following chondrite values (in $\mathrm{ppm}$ ) were used: $\mathrm{La}=$ $0.315 ; \mathrm{Ce}=0.813 ; \mathrm{Nd}=0.5966 ; \mathrm{Sm}=0.1917 ; \mathrm{Eu}=$ $0.07216 ; \mathrm{Tb}=0.049 ; \mathrm{Dy}=0.325 ; \mathrm{Yb}=0.2075 ;$ and $\mathrm{Lu}=$ 0.03225 (Masuda, 1975). In describing the REE characteristics of basalts, several parameters are of interest. As a measure of the degree of fractionation of the light rare earths (LREE) the ratio $\mathrm{La} / \mathrm{Sm}$ (normalized to chondrite) is used and referred to as $\mathrm{La} / \mathrm{Sm}$ e.f. For typical mid-ocean ridge basalts (MORB) this value is below unity; that is, the normalized distribution patterns are LREE-depleted. To characterize the fractionation of the heavy rare earths (HREE) a similar ratio, $\mathrm{Sm} / \mathrm{Yb}$ e.f., can be used. Often the HREE are almost unfractionated; that is, they exhibit chondritic patterns. Therefore, the $\mathrm{Yb}$ e.f. provides a reasonable measure for the overall enrichment of the HREE. A characteristic feature in the REE distribution curve of some basalts is the occurrence of a positive or negative Eu anomaly (Puchelt and Emmermann, 1977). These anomalies are expressed by a value Eu*, which is the ratio of the normalized Eu value of the sample to the interpolated Eu value obtained when the adjacent REE are connected by a smooth distribution curve.

The chondrite-normalized REE patterns of the investigated basalts are given in Figures 2 through 5, which correspond to the four major lithologic groups encountered in the hole. In order to show the relationship of the patterns with depths, sub-bottom depth for each sample is given. As can be seen from these figures, the basalts analyzed exhibit in general very similar REE distributions. All samples are LREE-depleted, the $\mathrm{La} / \mathrm{Sm}$ e.f. varying between 0.44 and 0.94 . Only one sample (uppermost in Figure 3) shows an almost unfractionated pattern with a very slight linear increase in the concentrations from $\mathrm{La}$ to $\mathrm{Lu}$ and an overall
REE enrichment of about 18 compared to chondrite. Minor differences exist in the shape of the curves and in the enrichment factors. Most samples are more or less unfractionated for the HREE. In some cases a maximum is found for the intermediate REE (Sm- Tb); Tb to Lu showing a decrease. Significant anomalous behavior of Eu cannot be observed. In all cases, the Eu values found are on or very close to the distribution curve constructed as a smooth regression line.

As far as the REE level is concerned, there is an obvious difference between the samples of lithologic Unit 4 and the other units. Basalts from Unit 4 are, in general, characterized by the lowest REE abundances. The La values are only 5 to 10 times the chondritic value, whereas in all other units the La enrichment is between 9 and 17. The HREE enrichment level of Unit 4 shows a variation from 11 to 17 as compared to 18 to 24 of the other units. The similarity of the other lithologic units and marked differences between these and Unit 4 is also evident in Table 3, which gives the averages of all elements determined.

Among the other trace elements determined, Sc is probably most pertinent in distinguishing between the different units. It shows a very limited variation in all lithologic units, and its concentrations in Unit 4 are much lower as compared to the other units. The same is true for Hf; however, the scatter of Hf (except in Unit 3) is much larger. Unit 4 is also distinguishable from the other units with regard to the average V, Cr, and $\mathrm{Zn}$ concentrations (Table 3 ). The $\mathrm{Cr}$ content is highest in basalts of Unit 4, whereas $\mathrm{V}$ and $\mathrm{Zn}$ are lowest. The $\mathrm{Sr}$ abundances deviate from this general picture. They are lowest in Unit 4 but surprisingly enough are similar to the $\mathrm{Sr}$ concentrations found in Units 1 and 2, whereas Units 3 and 5 through 8 have higher average values. Fluorine and especially lithium show relatively large variations. Furthermore, the average $\mathrm{Li}$ values of different units are similar.

A comparison of the present data with the average composition of "abyssal oceanic tholeiites" (last column in Table 3) as given by Wedepohl (1975) shows that the Leg 46 basalts in their REE, $\mathrm{Cr}$, and V contents are very close to the 

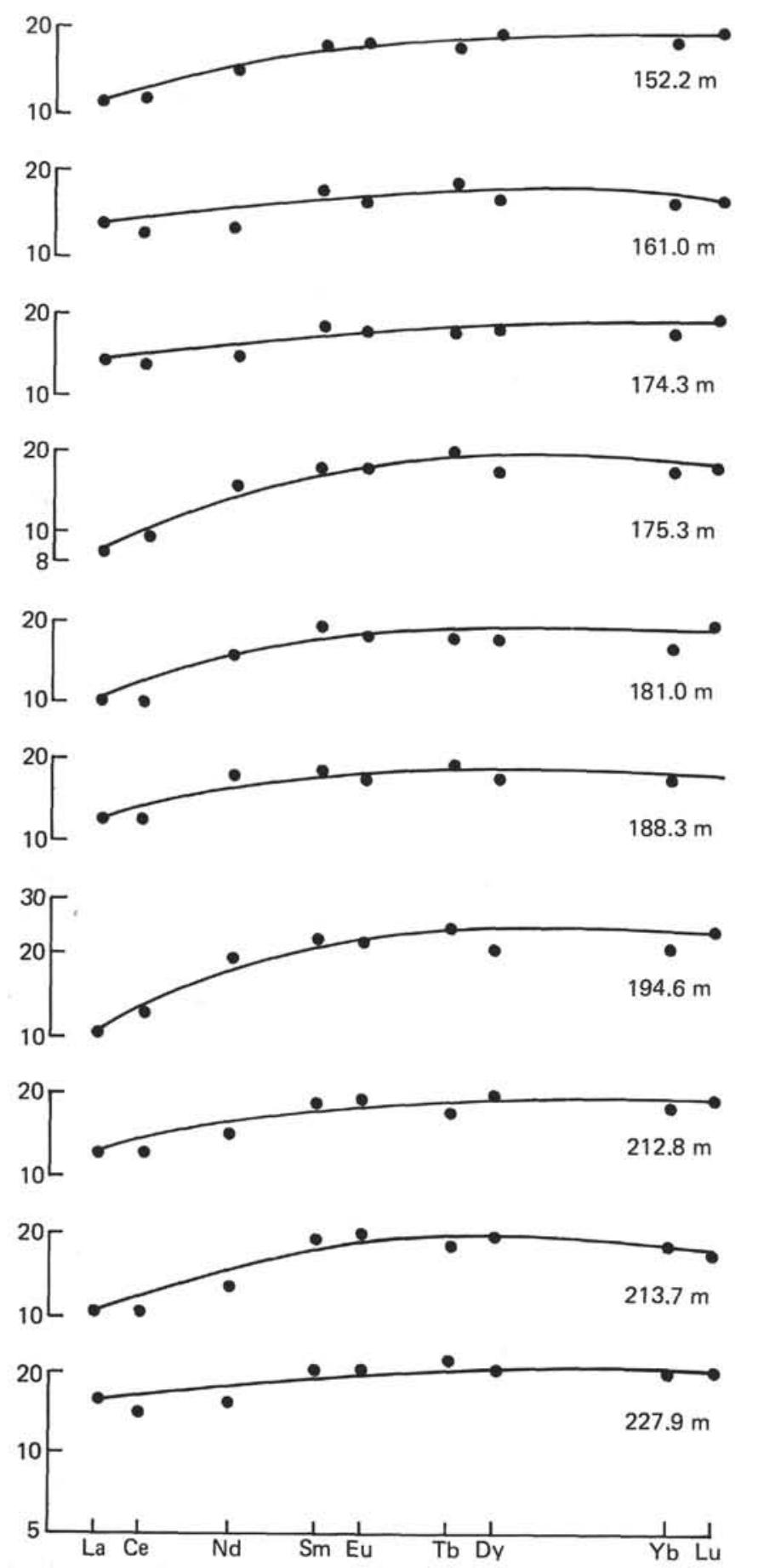

Figure 2. Chondrite-normalized REE patterns of Leg 46 basalts (lithologic Units 1 and 2).

abyssal oceanic tholeiite of Wedepohl. The dissimilarity in case of the other trace elements may be due to the fact that too few analyses are available for averaging.

\section{DISCUSSION}

The REE and other trace element data indicate that there are no large-scale differences between the basalts from different lithologic units of Hole 396B. However, minor differences do exist, and these are especially marked in case

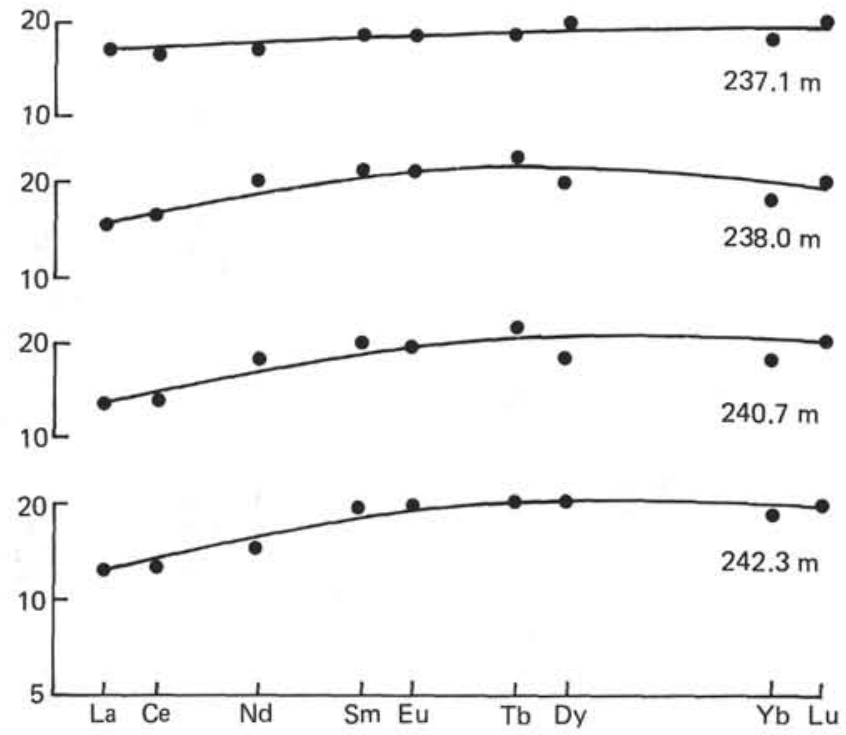

Figure 3. Chondrite-normalized REE patterns of Leg 46 basalts (lithologic Unit 3).

of the REE. When the data set is closely scrutinized, lithologic Unit 4 stands out, whereas the other units are very similar in composition. This is also in keeping with the major element chemistry (Dmitriev, Heirtzler, et al., 1976) and can be related to the rather specific petrographic features of this basalt sequence. It might be recalled here that Unit 4 consists of highly phyric pillow basalts which contain up to 20 per cent phenocrysts of plagioclase and up to 6 per cent phenocrysts of olivine. Additionally, microphenocrysts of spinel occur in small amounts.

This mineralogical composition directly reflects the trace element abundances. The overall low concentration of REE in Unit 4 is due to the fact that early phases of plagioclase and olivine hardly concentrate any appreciable amount of REE, and as such, their presence in larger concentrations in any subsequent liquid would result in dilution of REE, when whole rock analysis of the liquid and crystal cumulates together is made. On the other hand, the concentration of olivine will cause an enrichment of $\mathrm{Ni}$, and the occurrence of spinelmicrophenocrysts is responsible for the observed $\mathrm{Cr}$ enrichment. The significantly lower concentration of Sc can be attributed to a smaller amount of clinopyroxene in this unit, which is the major Sc carrier.

The trace element data thus support the view that the basalt sequence of Hole 396B was built up by the extrusion of several compositionally slightly different magma batches. The general depletion of the LREE in all samples can only be explained if these magmas are derived from a LREE-depleted mantle source. Furthermore, the absence of any considerable degree of variation in the shape of the REE distribution curves, as well as the absence of Eu anomalies, may indicate that these magmas have not undergone any large-scale differentiation after their generation.

\section{ACKNOWLEDGMENTS}

Special thanks are due to Dr. R.K. Srivastava (Karlsruhe) for his help in preparing the English text and for many useful discussions. The investigations were supported by Deutsche Forschungsgemeinschaft. U. Kramar made INAA determinations with 

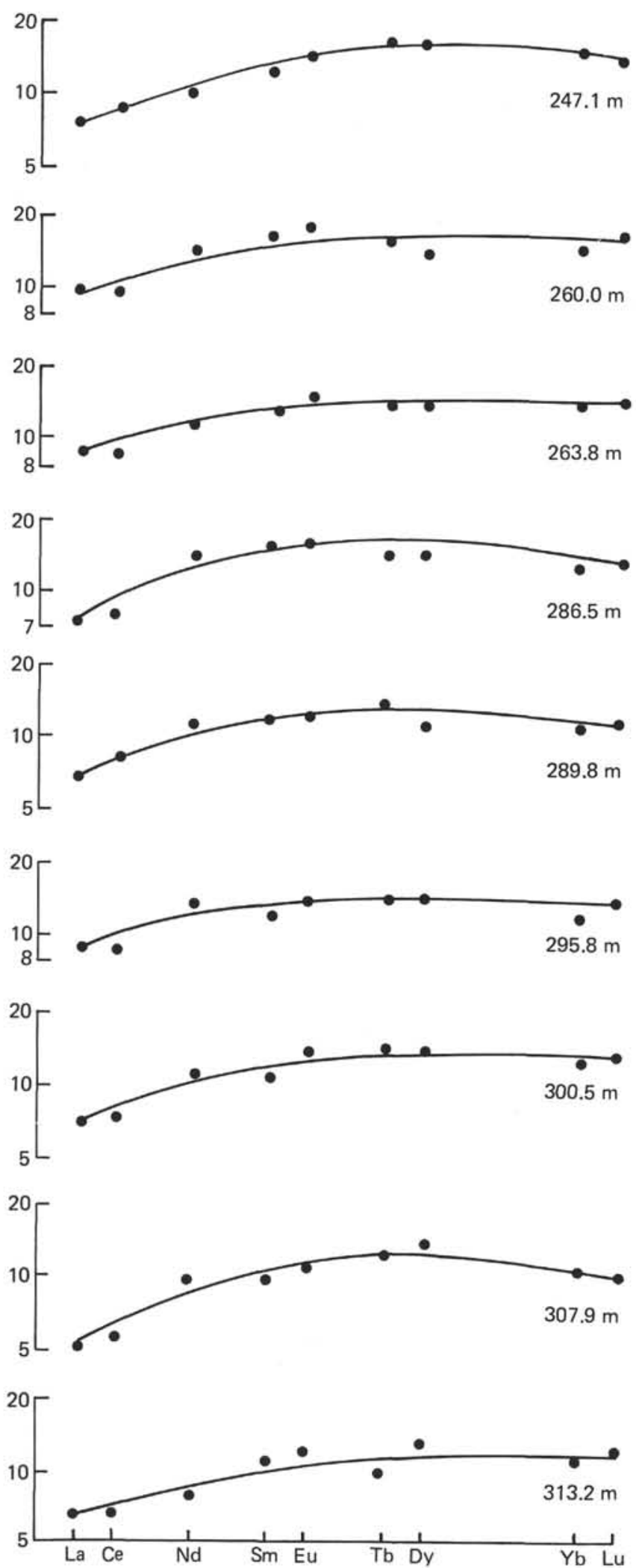

Figure 4. Chondrite-normalized REE patterns of Leg 40 basalts (lithologic Unit 4).

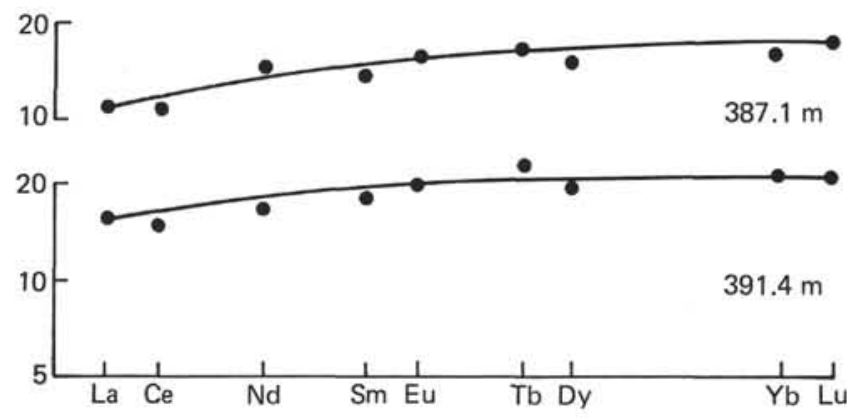

Figure 5. Chondrite-normalized REE patterns of Leg 46 basalts (lithologic Unit 7).

TABLE 3

Average Chemical Composition (in ppm) of the Five Lithologic Units of Hole 396B (Leg 46)

\begin{tabular}{c|cccc|c}
\hline & \multicolumn{4}{|c|}{ Lithologic Units } & \multirow{2}{*}{$\begin{array}{c}\text { Abyssal Oceanic } \\
\text { Tholeite }\end{array}$} \\
\cline { 2 - 5 } Element & 1 and 2 & 3 & 4 & 5 & 8 \\
\hline $\mathrm{Li}$ & 16 & 14 & 15 & 17 & No value \\
$\mathrm{F}$ & 198 & 178 & 169 & 275 & $52(?)$ \\
$\mathrm{Sc}$ & 37.9 & 37.8 & 31.0 & 34.5 & 303 \\
$\mathrm{~V}$ & 294 & 301 & 242 & 300 & 298 \\
$\mathrm{Cr}$ & 309 & 286 & 328 & 303 & 119 \\
$\mathrm{Ni}$ & 143 & 147 & 152 & 141 & 84 \\
$\mathrm{Zn}$ & 69 & 71 & 51 & 67 & 121 \\
$\mathrm{Sr}$ & 136 & 151 & 133 & 152 & 3.8 \\
$\mathrm{La}$ & 3.7 & 4.3 & 2.5 & 4.5 & 12.4 \\
$\mathrm{Ce}$ & 10.5 & 11.8 & 7.2 & 11.3 & 10.7 \\
$\mathrm{Nd}$ & 9.7 & 10.6 & 7.5 & 10.3 & 3.7 \\
$\mathrm{Sm}$ & 3.8 & 4.0 & 2.5 & 3.2 & 1.3 \\
$\mathrm{Eu}$ & 1.22 & 1.32 & 0.93 & 1.23 & 0.8 \\
$\mathrm{~Tb}$ & 0.93 & 0.96 & 0.67 & 0.88 & 6.2 \\
$\mathrm{Dy}$ & 6.1 & 6.5 & 4.6 & 6.3 & 2.9 \\
$\mathrm{Yb}$ & 3.7 & 3.8 & 2.6 & 3.5 & 0.52 \\
$\mathrm{Lu}$ & 0.62 & 0.64 & 0.45 & 0.62 & No value \\
$\mathrm{Hf}$ & 2.2 & 2.5 & 1.7 & 2.3 & \\
\hline
\end{tabular}

equipment provided by Ministerium für Forschung und Technologie, F.R.G. The samples were irradiated in the Nuclear Reactor, Karlsruhe, with financial support of the KFZ. We thank all individuals and institutions who contributed to this investigation.

\section{REFERENCES}

Dmitriev, L.V., Heirtzler, J.R., et al., 1976. Drilling into ocean crust, Geotimes, p. 21-23.

Flanagan, F.J., 1973. Values for international geochemical reference samples, Geochim. Cosmochim. Acta, v. 37, p. 1189-1200.

Ingram, B.L., 1970. Determination of fluoride in silicate rocks without separation of aluminum using a specific ion electrode, Analytical Chemistry, v. 42 , p. 1825-1827.

Masuda, A., 1975. Abundances of monoisotopic REE, consistent with the Leedey chondrite value, Geochim. J., v. 9, p. 183-184.

Puchelt, H. and Emmermann, R., 1977. REE Characteristics of Ocean Floor Basalts from the MAR $37^{\circ} \mathrm{N}$ (Leg 37 DSDP), Contrib. Mineral. Petrol., v. 62, p. 43-52.

Puchelt, H., Emmermann, R., and Kramar, U., 1976. The bearing of trace element distribution patterns of deep sea basalts for the interpretation of their genesis, Journal of Radioanalytical Chemistry; 1976 International Conference "Modern Trends in Activation Analysis," v. II, p. 1049-1056.

Wedepohl, K.H., 1975. The contribution of chemical data to assumptions about the origin of magmas from the mantle, Fortschr. Miner., v. 52, p. 141-172. 